\title{
Patterns of flea infestation in rodents and insectivores from intensified agro-ecosystems, Northwest Spain
}

Silvia Herrero-Cófreces ${ }^{1,2^{*}+}$ (D), Manuel Fabio Flechoso ${ }^{1,3 \dagger}$, Ruth Rodríguez-Pastor ${ }^{1,2}$, Juan José Luque-Larena ${ }^{1,2+}$ and François Mougeot ${ }^{4 \dagger}$

\begin{abstract}
Background: Fleas frequently infest small mammals and play important vectoring roles in the epidemiology of (re) emerging zoonotic disease. Rodent outbreaks in intensified agro-ecosystems of North-West Spain have been recently linked to periodic zoonotic diseases spillover to local human populations. Obtaining qualitative and quantitative information about the composition and structure of the whole flea and small mammal host coexisting communities is paramount to understand disease transmission cycles and to elucidate the disease-vectoring role of flea species. The aims of this research were to: (i) characterise and quantify the flea community parasiting a small mammal guild in intensive farmlands in North-West Spain; (ii) determine and evaluate patterns of co-infection and the variables that may influence parasitological parameters.
\end{abstract}

Methods: We conducted a large-scale survey stratified by season and habitat of fleas parasitizing the small mammal host guild. We report on the prevalence, mean intensity, and mean abundance of flea species parasitizing Microtus arvalis, Apodemus sylvaticus, Mus spretus and Crocidura russula. We also report on aggregation patterns (variance-tomean ratio and discrepancy index) and co-infection of hosts by different flea species (Fager index) and used generalized linear mixed models to study flea parameter variation according to season, habitat and host sex.

Results: Three flea species dominated the system: Ctenophthalmus apertus gilcolladoi, Leptopsylla taschenbergi and Nosopsyllus fasciatus. Results showed a high aggregation pattern of fleas in all hosts. All host species in the guild shared C. a. gilcolladoi and N. fasciatus, but L. taschenbergi mainly parasitized mice (M. spretus and A. sylvaticus). We found significant male-biased infestation patterns in mice, seasonal variations in flea abundances for all rodent hosts (M. arvalis, M. spretus and A. sylvaticus), and relatively lower infestation values for voles inhabiting alfalfas. Simultaneous co-infections occurred in a third of all hosts, and $\mathrm{N}$. fasciatus was the most common flea co-infecting small mammal hosts.

Conclusions: The generalist N. fasciatus and C. a. gilcolladoi dominated the flea community, and a high percentage of co-infections with both species occurred within the small mammal guild. Nosopsyllus fasciatus may show higher

\footnotetext{
*Correspondence: silvia.herrero.cofreces@uva.es

tSilvia Herrero-Cófreces and Manuel Fabio Flechoso contributed equally to this work

†Juan José Luque-Larena and François Mougeot contributed equally to this work and supervision

1 Dpto. Ciencias Agroforestales, ETSIIAA, Universidad de Valladolid, Avda. de Madrid 44, 34004 Palencia, Spain

Full list of author information is available at the end of the article
}

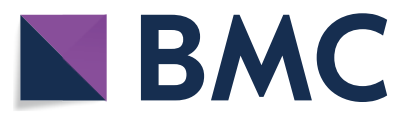

(c) The Author(s) 2020. This article is licensed under a Creative Commons Attribution 4.0 International License, which permits use, sharing, adaptation, distribution and reproduction in any medium or format, as long as you give appropriate credit to the original author(s) and the source, provide a link to the Creative Commons licence, and indicate if changes were made. The images or other third party material in this article are included in the article's Creative Commons licence, unless indicated otherwise in a credit line to the material. If material is not included in the article's Creative Commons licence and your intended use is not permitted by statutory regulation or exceeds the permitted use, you will need to obtain permission directly from the copyright holder. To view a copy of this licence, visit http://creativeco mmons.org/licenses/by/4.0/. The Creative Commons Public Domain Dedication waiver (http://creativecommons.org/publicdomain/ zero/1.0/) applies to the data made available in this article, unless otherwise stated in a credit line to the data. 
competence of inter-specific transmission, and future research should unravel its role in the circulation of rodentborne zoonoses.

Keywords: Aggregation, Apodemus sylvaticus, Crocidura russula, Ectoparasite, Host sex effects, Microtus arvalis, Mus spretus, Seasonal variations, Siphonaptera co-infection

\section{Background}

Fleas are abundant ectoparasites that frequently infest mammals and birds [1]. These haematophagous insects can act as vectors of numerous pathogens transmitted through biting or by direct contact with their faeces [1] and often play a relevant role in the circulation and epidemiology of emerging and re-emerging diseases worldwide $[1,2]$. Fleas spread the well-studied plague, caused by Yersinia pestis [3], as well as other emerging pathogens that cause zoonoses such as rickettsioses (murine typhus and flea-borne spotted fever) and bartonelloses [1]. Fleas also maintain and transmit pathogens causing tularemia, Q fever, trypanosomiasis and myxomatosis and can act as intermediate hosts for some helminthiases $[1,4]$. Comprehensive knowledge of flea ecology becomes essential to uncover their role in the circulation of diseases in nature. For instance, patterns of flea distribution and abundance in host communities, seasonal variation of such patterns, relationships with individual host characteristics (e.g., host sex, age, condition, immune function), the effect of environmental habitat and conditions (temperature, humidity) and co-infection, are all relevant aspects that need to be quantified to build any baseline knowledge required to understand flea life cycles and their relative ecological and epidemiological roles $[5,6]$.

Many fleas parasitize rodents [1], which account for $25 \%$ of all living mammals and act as the main host type for $>80 \%$ of all known flea species [5]. Rodents are a key mammal group in terms of public health, as they are involved in the amplification and spillover of many zoonoses affecting humans globally [7], and their fleas often play significant vectoring roles in the transmission cycles of disease [7-9]. In Northwest Spain, common vole (Microtus arvalis) populations massively invaded lowland agricultural landscapes between the 1970s and 1990s, putatively colonizing newly irrigated fodder crops from natural peripheral mountainous habitats [10-12]. In recently colonized farmland, common vole populations are cyclic [13] and periodically become a crop pest when overabundant, causing serious public health impacts due to the amplification and spillover of zoonotic diseases like tularemia $[10,14,15]$. In these intensively farmed landscapes, common voles coexist in the same microhabitats with other sympatric rodents and insectivores (mainly, wood mouse Apodemus sylvaticus, Algerian mouse Mus spretus and greater white-toothed shrew Crocidura russula) [16]. Characteristics of the host (morphological, physiological, immunological, behavioural and phylogenetic traits) and their shelters (i.e. burrows, nests) are critical to flea lifecycles $[1,5]$. In other study systems, flea specificity is an important trait influencing the flea community $[17,18]$. Fleas can infest hosts phylogenetically close [18], switching between coexisting species within guilds [19]. Host density is also a relevant factor to consider since it involves variations in flea species richness $[20,21]$. Furthermore, climatic conditions, local factors and specific host features shape infestation patterns at the local level [18, 22-24]. Due to all these sources of variation, general patterns should not be inferred but studied in detail in local flea communities.

In the Palearctic region, up to 6 different taxonomic families of fleas can infest small mammals [1], and 68 flea species have been identified to date in the Iberian peninsula [25]. Three of these flea families occur in Northwest Spain: Ceratophyllidae, Ctenophthalmidae and Pulicidae [26-29]. Recent surveys reported that the main flea species infesting common voles in intensive farmland of Northwest Spain were Ctenophthalmus apertus, Nosopsyllus fasciatus and Leptopsylla taschenbergi [30].

Fleas parasitizing common voles in Northwest Spain are known to harbour zoonotic bacteria such as Francisella tularensis (i.e. the etiological agent of tularemia) and several Bartonella species (agent of bartonelloses) [30]. Yet, nothing is known about flea distribution, relative abundance and co-infection patterns within and between the small mammal host guild. Improving our basic knowledge on how fleas interact with their local hosts in farming landscapes will aid in the understanding of disease circulation in landscapes frequently scourged by rodent-driven zoonoses. Here we report on the patterns of flea infestation in the small mammal community inhabiting the intensively farmed landscapes in Northwest Spain dominated by colonizing common voles. Specifically, we document and quantify flea-host specificity and describe patterns of abundance, prevalence, intensity and aggregation of each flea species on each of the main small mammal hosts. We also evaluated patterns of flea co-infection in hosts and studied relative abundance variation according to season, habitat (i.e. crop type) and host sex. 


\section{Methods}

\section{Study area}

The study was conducted in intensively farmed landscapes in the Castilla-y-León region, Northwest Spain. These landscapes are steppe-like crop mosaics dominated by cereal fields (mainly wheat and barley) with scattered irrigated crops (e.g. sweet beet, sunflower, corn and alfalfa) and interspersed by remnant semi-natural vegetation (fallows or set-aside, field margins, grassy road verges and wildflower strips; [16]). Climate is continental-Mediterranean, characterized by wide seasonal temperature oscillations: long, cold and humid winters with frequent frost events, followed by dry and hot summers with variable but persistent drought periods; precipitation is mostly concentrated during spring and autumn [31].

\section{Study small mammals}

In the studied habitats, the bulk (>95\%) of the small mammal community includes three rodents and one insectivore: common voles (M. arvalis), wood mice ( $A$. sylvaticus), Algerian mice (M. spretus) and white-toothed shrews (C. russula) [16]. The common vole is a fossorial rodent [32] characterized by population peaks recorded every 3 years [13], whereas the two mouse species show seasonal fluctuations [33, 34]. Microtus arvalis have a preference for permanent herbaceous fields [16], while A. sylvaticus is a habitat generalist species [33] and $M$. spretus prefers Mediterranean open habitat ecosystems [34]. The white-toothed shrew selects forest edges and open habitats with high vegetation cover [35].

\section{Small mammal trappings}

Fieldwork consisted of seasonal live trappings (March, July and November) conducted at three independent localities (>60 km apart) in the provinces of Palencia $\left(42^{\circ} 01 \mathrm{~N}, 4^{\circ} 42^{\prime} \mathrm{W}\right)$, Valladolid $\left(41^{\circ} 34 \mathrm{~N}, 5^{\circ} 14 \mathrm{~W}\right)$ and Zamora $\left(41^{\circ} 50 \mathrm{~N}, 5^{\circ} 36^{\top} \mathrm{W}\right)$, all within the Castilla-y-León region. Between July 2009 and July 2015, we monitored six study areas (two replicates per locality, each replicate consisted of an area of $c .40 \mathrm{~km}^{2}$ ). In each study area, we sampled the three most relevant habitats: cereals (most abundant crop type), alfalfas (most favourable crop type in terms of cover and food availability for voles) and fallows (see [16] for more details on trapping procedures and habitat use by voles). In brief, we randomly selected 12 fields (4 cereals, 4 alfalfas and 4 fallows) amongst those available in a given area, avoiding sampling the same locations during consecutive seasonal trappings, and set 35 traps in each field $(8 \mathrm{~cm} \times 9 \mathrm{~cm} \times 23 \mathrm{~cm}$; LFAHD Sherman $\odot$ ) interspaced $2 \mathrm{~m}$ and deployed in a T-line shape from field margins towards the inside of crop fields [16]. Traps were baited with carrot and apple and set for $24 \mathrm{~h}$. Each trapped animal was provided with a unique code (we noted the date, site and crop field where it was trapped). For this study, we captured and sampled 2254 small mammals belonging to the species $M$. arvalis (61.2\%), A. sylvaticus (23.1\%), M. spretus (13.5\%), C. russula $(1.9 \%)$ and other species $(0.3 \%)$.

\section{Flea collection from trapped animals and identification}

Captured rodents and shrews were individually transferred to laboratory animal plastic cages $\left(29 \times 22 \times 14 \mathrm{~cm} ;\right.$ Panlab $\left.^{\circledR}\right)$. To follow the ethical legislation about the welfare of animals used in research [36], and to maximise the number of animals that arrived alive to the laboratory, we provided captured animals with food, water and bedding material until the euthanasia procedure. In the laboratory, each animal was sexed, weighted and killed with $\mathrm{CO}_{2}$, following a humane protocol approved by the University of Valladolid Ethics Committee for Animal Research (code: 4801646). Immediately after death, fleas were carefully collected from each animal by blowing the fur and combing it with a lice comb while holding the animal over a white plastic pan $(520 \times 420 \times 95 \mathrm{~mm})$ half-filled with water. Fleas from each individual were counted, collected from the water surface using a pair of tweezers and stored in individually labelled tubes filled with $70 \%$ ethanol $[37,38]$. We ensured that no fleas were missed from each individual by placing the animal carcasses in sealed plastic bags and leaving them for $1 \mathrm{~h}$ in the refrigerator before checking again for fleas. Fleas were subsequently studied with a $10 \times$ and $40 \times$ optical microscope (Nikon Optiphot-2) and identified at the species level using dichotomous keys [39]. We collected a total of 4715 fleas from 1239 small mammal hosts: 3900 fleas from M. arvalis $(\mathrm{n}=941), 698$ from $A$. sylvaticus ( $\mathrm{n}=238), 87$ from $M$. spretus $(\mathrm{n}=49)$, 14 from C. russula $(\mathrm{n}=6)$ and 16 from other small mammals $(\mathrm{n}=5)$. A total of 4266 individual fleas were identified.

\section{Data analysis}

For each host species, we obtained information on the prevalence, mean abundance and mean intensity of each flea species (following Bush et al. [40]). Data were summarized as prevalence $\pm 95 \%$ confidence intervals (CI; traditional Clopper-Pearson confidence limits) and mean intensity or abundance \pm standard error (SE). We also quantified the level of skewness of the flea distribution on hosts (a measure of the asymmetry of the probability distribution of a real-valued random variable about its mean) using two complementary indices: (i) the variance-to-mean ratio (VMR); (ii) the discrepancy index (D) following Poulin [41]. Co-infection was also quantified (hosts infested by more than one flea species). These 
descriptive statistics were obtained using the Quantitative Parasitology (QPweb) software version 1.0.14 [42]. We used the Fager index [43] to determine the degree of co-occurrence of flea species, regardless of abundance variations. This index ranges between 0 (species never infest simultaneously) and 1 (species always co-occur) and was calculated as follows:

$$
I_{\mathrm{AB}}=2 J /\left(N_{\mathrm{A}}+N_{\mathrm{B}}\right)
$$

$J$ is the number of hosts where parasitic species A and B are present simultaneously; $N_{\mathrm{A}}$ is the number of hosts with species A present; $N_{\mathrm{B}}$ is the number of hosts with species B present.

Co-infection differences according to host sex were tested using Pearson's chi-square tests or G-tests, depending on minimum sample sizes. For rodent hosts, we studied flea prevalence, mean intensity and mean abundance variation according to sampling month, crop type (except for $M$. spretus because of the small sample size) and host sex. We used generalized linear mixed-effects models (GLMM) and a negative binomial distribution for intensity and abundance. Models included the factors year (2009-2015) and site (Palencia/Valladolid/Zamora) as random terms (to account for possible temporal or spatial variations) whenever possible and the factors habitat (crop), type (alfalfa/ cereal/fallow), host sex (male/female), and season/ month (November/March/July) as explanatory variables. Because of sample size limitations, some mixed models did not converge. We then included site or site and year as fixed effects instead of random effects. The model selection followed a backwards selection procedure (using the "drop1" function in R), sequentially removing non-significant interactions and factors (we report both significant, $P=0.05$ level, and marginally significant, $P=0.10$ level, effects). Differences between levels of the categorical factors (crop type and month) were tested using post-hoc Tukey tests. Statistical models were carried out using the "lme4" [44] and "R2admb" [45] packages, and G-tests using "RVAideMemoire" [46] of the R3.6.1 software [47].

\section{Results}

\section{Flea community}

The flea community included the following species: Ctenophthalmus apertus apertus $(n=2), C$. a. gilcolladoi $(n=1879)$, C. baeticus baeticus $(n=11)$, Leptopsylla taschenbergi amitina $(n=460)$, Nosopsyllus fasciatus $(n=1903)$ and Rhadinopsylla beillardae $(n=8)$; in addition, two specimens were identified at genus level only (Ctenophthalmus spp.). Two species dominated the small mammal flea community: $N$. fasciatus and C. $a$. gilcolladoi (frequency $=44.6 \%$ and $44.1 \%$, respectively), followed by $L$. taschenbergi (10.8\%). Patterns of flea infestation differed between small mammal host species (Table 1 and Fig. 1; complementary information in Additional file 1: Figure S1). The most abundant flea species infesting common voles were $N$. fasciatus and C. a. gilcolladoi, representing $98.5 \%$ of all fleas identified (48.5\% and $50.0 \%$, respectively). By contrast, $L$. taschenbergi was the most abundant flea infesting mice (56\% and $48 \%$ of all fleas for $A$. sylvaticus and M. spretus, respectively). Shrews were only infested by C. a. gilcolladoi and N. fasciatus. Other Ctenophthalmus spp. different from C. a. gilcolladoi (C. a. apertus, C. baeticus and Ctenophthalmus spp.) were seldom found in $M$. arvalis (in one, eight and two animals, respectively). The flea $R$. beillardae was occasionally identified in the most abundant rodent species (two fleas in two M. arvalis, five fleas in two A. sylvaticus and one flea in one M. spretus).

Overall, flea prevalence on small mammal hosts averaged 51.6\% ( $\mathrm{CI}=49.5-53.7)$, and intensity averaged 3.66 fleas per infested host $(\mathrm{SE}= \pm 0.15$; range $=0-68$ ), resulting in a mean abundance of $1.89(\mathrm{SE}= \pm 0.09)$. Detailed information on prevalence, mean abundance and mean intensity of each flea species and host is provided in Table 1 . Fleas were highly aggregated on their small mammal hosts (Table 1; D-index values close to 1). Variance-to-mean ratios were also indicative of a marked parasite aggregation, with greater ratios for those fleas typically more abundant on a given host (C. a. gilcolladoi and $N$. fasciatus for M. arvalis; L. taschenbergi for A. sylvaticus and $M$. spretus).

\section{Variation of flea parasitological parameters according to season, crop type and host sex}

Flea prevalence, mean intensity and mean abundance were highest in $M$. arvalis $(68.2 \%, \mathrm{CI}=65.7-70.6 ; 4.14$, $\mathrm{SE}= \pm 0.19$; and 2.83, $\mathrm{SE}= \pm 0.13$, respectively) and $A$. sylvaticus $(45.6 \%, \mathrm{CI}=413-50.0 ; 2.93, \mathrm{SE}= \pm 0.20$; and $1.34, \mathrm{SE}= \pm 0.11$, respectively) and noticeably lower in $M$. spretus $(16.1 \%, \mathrm{CI}=12.2-20.7 ; 1.78, \mathrm{SE}= \pm 0.21$; and $0.29, \mathrm{SE}= \pm 0.48$, respectively) and C. russula $(14.3 \%$, $\mathrm{CI}=5.40-28.5 ; 2.33, \mathrm{SE}= \pm 0.67$; and $0.33, \mathrm{SE}= \pm 0.15$, respectively). The most fleas per host were harboured by $M$. arvalis [range 1-68], followed by $A$. sylvaticus [range 1-29], while M. spretus [range 1-5] and C. russula [range 1-7] had fewer fleas per host. For further analyses of infestation patterns, we focused on the main flea species (C. a. gilcolladoi, N. fasciatus and L. taschenbergi) and the most frequently captured small mammal hosts (M. arvalis, A. sylvaticus and M. spretus) (Table 2).

Variation in C. a. gilcolladoi parameters on M. arvalis were significantly explained by month (prevalence: $X^{2}=26.82, d f=2, P<0.001$; intensity: $X^{2}=46.35$, 
Table 1. Parasitological parameters of the flea community of studied small mammal hosts studied

\begin{tabular}{|c|c|c|c|c|c|c|c|c|}
\hline $\begin{array}{l}\text { Host species }[n \\
\left.\text { total }^{2} / n \text { alive }{ }^{b}\right]\end{array}$ & Flea species & $\begin{array}{l}\text { n. identified } \\
\text { fleas [n } \\
\text { hosts }^{c} \text { ] }\end{array}$ & $\begin{array}{l}\text { Fleas } \\
\text { intensity } \\
\text { range }\end{array}$ & $\begin{array}{l}\text { Prevalence \% (95\% } \\
\text { CI) }\end{array}$ & $\begin{array}{l}\text { Mean intensity } \\
( \pm \text { SE) }\end{array}$ & $\begin{array}{l}\text { Mean } \\
\text { abundance } \\
( \pm \text { SE) }\end{array}$ & $\begin{array}{l}\text { Variance/ } \\
\text { mean } \\
\text { ratio }\end{array}$ & $\begin{array}{l}\text { Discrepancy index } \\
\text { Mean }(95 \% \mathrm{Cl})^{\mathbf{e}}\end{array}$ \\
\hline \multirow{3}{*}{$\begin{array}{c}\text { Microtus arvalis } \\
{[1380 / 941]}\end{array}$} & CAG & 1731 [539] & $1-18$ & $39.1(36.5-41.7)$ & $3.21(0.14)$ & $1.25(0.09)$ & 9.8 & $0.81^{f}(0.79-0.83)$ \\
\hline & NF & 1681 [643] & $1-30$ & $46.6(43.9-49.3)$ & $2.61(0.09)$ & $1.22(0.06)$ & 4.19 & $0.73^{f}(0.71-0.75)$ \\
\hline & $\mathrm{LT}$ & 34 [29] & $1-4$ & $2.1(1.4-3.0)$ & $1.17(0.01)$ & $0.02(0.01)$ & 1.45 & $0.98^{f}(0.97-0.99)$ \\
\hline \multirow{3}{*}{$\begin{array}{l}\text { Apodemus sylvati- } \\
\text { cus [522/238] }\end{array}$} & CAG & 116 [75] & $1-7$ & $14.4(11.5-17.7)$ & $1.55(0.06)$ & $0.22(0.03)$ & 2.2 & $0.90(0.87-0.92)$ \\
\hline & $\mathrm{NF}$ & 182 [116] & $1-7$ & $22.2(18.7-26.0)$ & $1.57(0.07)$ & $0.35(0.04)$ & 1.97 & $0.84(0.81-0.87)$ \\
\hline & LT & 387 [140] & $1-23$ & $26.8(23.1-30.8)$ & $2.76(0.17)$ & $0.74(0.09)$ & 5.21 & $0.85(0.82-0.87)$ \\
\hline \multirow{3}{*}{$\begin{array}{c}\text { Mus spretus } \\
{[304 / 49]}\end{array}$} & CAG & $13[11]$ & $1-3$ & $3.6(1.8-6.4)$ & $1.18(0.09)$ & $0.04(0.01)$ & 1.42 & $0.97(0.95-0.98)$ \\
\hline & $\mathrm{NF}$ & $29[21]$ & $1-5$ & $6.9(4.3-10.4)$ & $1.38(0.14)$ & $0.10(0.02)$ & 1.88 & $0.94(0.92-0.97)$ \\
\hline & LT & $39[18]$ & $1-7$ & $5.9(3.5-9.2)$ & $2.17(0.22)$ & $0.13(0.04)$ & 3.24 & $0.96(0.94-0.97)$ \\
\hline \multirow{2}{*}{$\begin{array}{l}\text { Crocidura russula } \\
\text { [42/6] }\end{array}$} & CAG & $7[2]$ & $2-5$ & $4.8(0.6-16.2)$ & $3.50(0.83)$ & $0.17(0.13)$ & 4.07 & $0.94(0.86-0.95)$ \\
\hline & $\mathrm{NF}$ & $7[5]$ & $1-3$ & $11.9(4.0-25.6)$ & $1.40(0.40)$ & $0.17(0.08)$ & 1.73 & $0.89(0.79-0.95)$ \\
\hline \multirow{2}{*}{$\begin{array}{l}\text { Microtus lusitanicus/ } \\
\text { duodecimcostatus } \\
{[4 / 3]}\end{array}$} & CAG & $12[3]$ & $2-6$ & - & - & - & - & - \\
\hline & $\mathrm{NF}$ & $2[1]$ & 2 & - & - & - & - & - \\
\hline Mustela nivalis [2/2] & NF & 2 [2] & 1 & - & - & - & - & - \\
\hline
\end{tabular}

SE, standard error; CAG, Ctenophthalmus apertus gilcolladoi; NF, Nosopsyllus fasciatus; LT, Leptopsylla taschenbergi.

a Number of total hosts captured

${ }^{b}$ Number of hosts brought alive to the laboratory and killed, infested or uninfested

c Number of hosts infested with all fleas identified

d $95 \%$ Confidence interval by Clopper-Pearson

e $95 \%$ Confidence interval by bootstrap method

f Sample too big for bootstrap confident limits; the percentile method was used instead

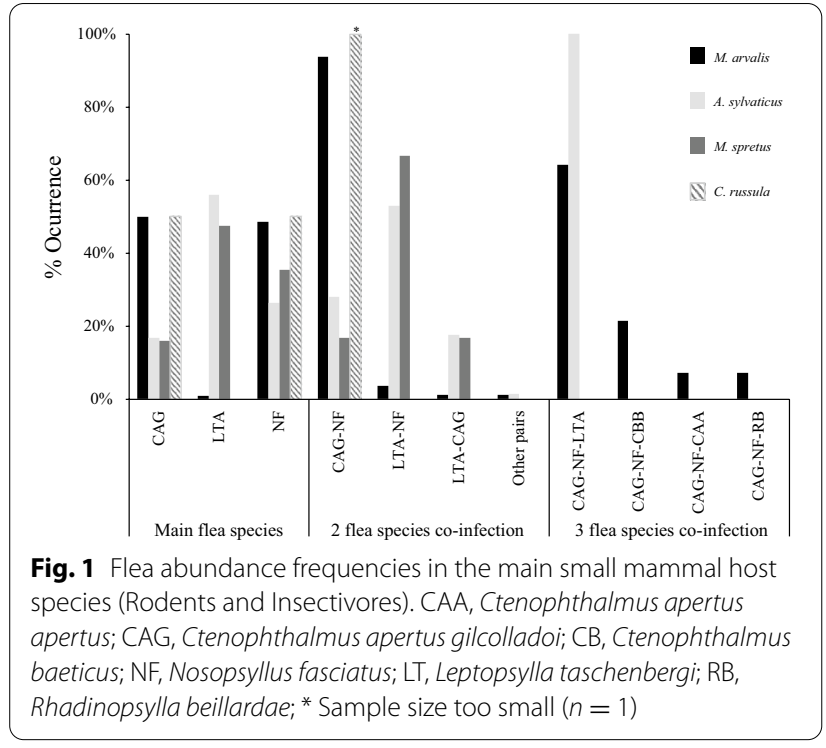

$d f=2, P<0.001 ;$ abundance: $X^{2}=34.53, d f=2$, $P<0.001$ ) and crop type (prevalence: $X^{2}=5.25, d f=2$, $P=0.073^{*}$; intensity: $X^{2}=9.85, d f=2, P=0.007$; abundance: $\left.X^{2}=14.65, d f=2, P<0.001\right)$, but not by host sex. Post-hoc tests (Tukey) indicated that C. a. gilcolladoi infestation was less frequent and severe on voles in July than March, with intermediate values in November. Moreover, voles caught in alfalfa had lower flea prevalence, abundance and intensity than those from fallows. In A. sylvaticus, C. a. gilcolladoi parameters differed between sexes (prevalence: $X^{2}=6.45, d f=1, P=0.011$; intensity: $X^{2}=8.10, d f=1, P=0.004$; abundance: $X^{2}=9.44, d f=1, P=0.002$ ), being greater for male than female hosts. The only exception was mean intensity, which reached higher values in animals trapped during March than in July. In M. spretus, neither variable explained C. a. gilcolladoi prevalence variation. The small sample size for this species did not allows us to analyse intensity or abundance.

Regarding $N$. fasciatus, we found in voles the same pattern as in C. a. gilcolladoi, with differences in the three parameters between crop types (prevalence: $X^{2}=24.15$, $d f=2, P<0.001$; intensity: $X^{2}=30.45, d f=2, P<0.001$; abundance: $\left.X^{2}=43.28, d f=2, P<0.001\right)$ and months (prevalence: $X^{2}=26.82, d f=2, P<0.001$; intensity: $X^{2}=13.23, d f=2, P=0.001$; abundance: $X^{2}=34.53$, $d f=2, P<0.001)$. Infestation with $N$. fasciatus was more frequent and severe during July, and lower levels of flea infestation were found in voles from alfalfas. In A. sylvaticus, $N$. fasciatus abundance did not differ between sexes, 


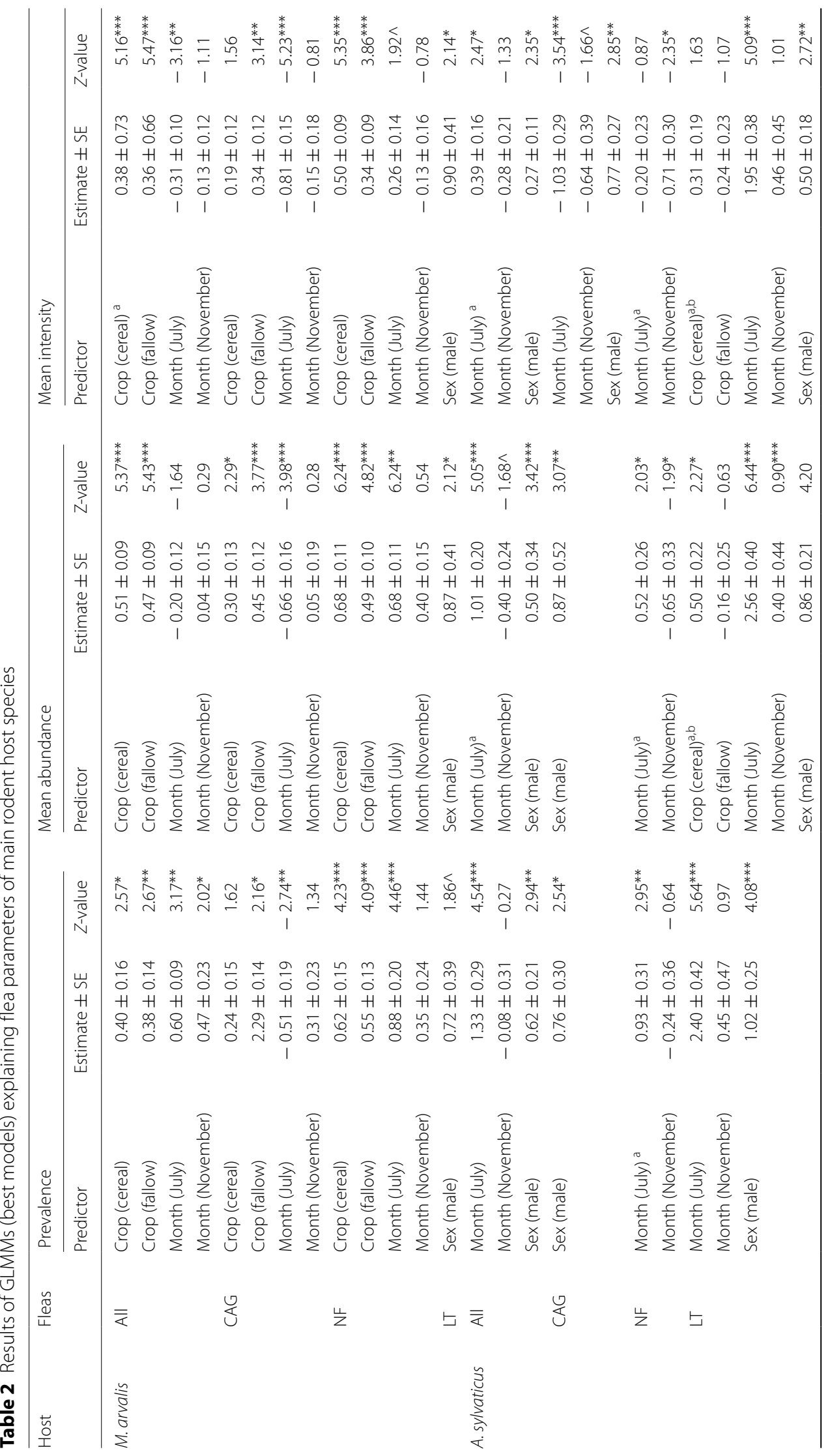




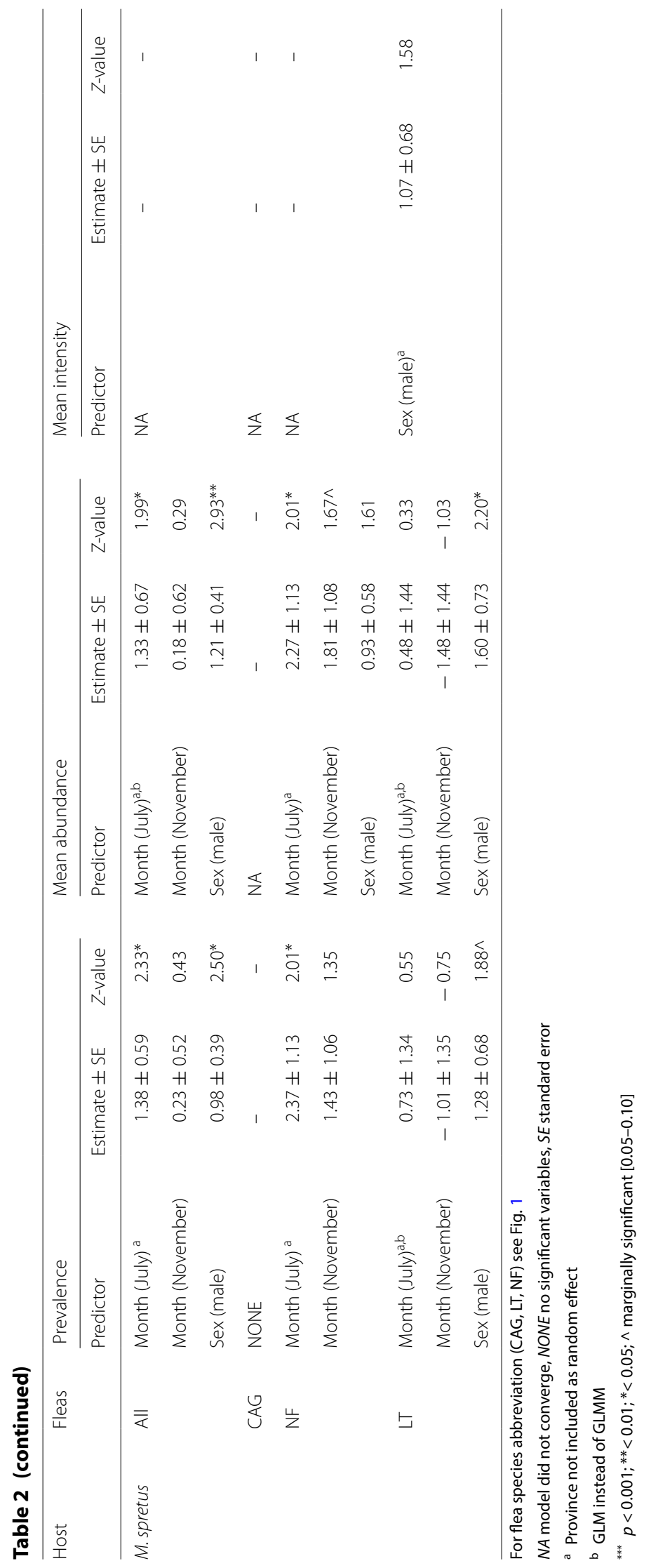


but varied between months (prevalence: $X^{2}=18.48$, $d f=2, P<0.001$; intensity: $X^{2}=5.92, d f=2, P=0.052^{*}$; abundance: $X^{2}=18.14, d f=2, P<0.001$ ), with a higher infestation rate during July and a reduced intensity and abundance during November. The infestation with this flea varied between months in M. spretus although the effect was only marginally significant (prevalence: $X^{2}=5.36, d f=2, P=0.069^{*}$; intensity: NA; abundance: $\left.X^{2}=5.48, d f=2, P=0.065^{*}\right)$. The highest prevalence rate was found in July but the mean abundance dropped in March. In M. spretus, $N$. fasciatus was also more abundant on males than females $\left(X^{2}=2.74, d f=1\right.$, $\left.P=0.0098^{*}\right)$. The small sample size for this species did not allow modelling intensity variation.

Regarding L. taschenbergi, we found that this flea was more abundant on males than on females in $M$. arvalis (prevalence: $X^{2}=3.47, d f=1, P=0.062^{*}$; intensity: $X^{2}=4.56, d f=1, P=0.032$; abundance: $X^{2}=4.50$, $d f=1, P=0.034)$. In both mouse species, we found a significant effect of sex (A. sylvaticus prevalence: $X^{2}=16.68, d f=1, P<0.001$; intensity: $X^{2}=7.28, d f=1$, $P=0.007$; abundance: $X^{2}=16.69, d f=1, P<0.001 ; M$. spretus prevalence: $X^{2}=4.30, d f=1, P=0.038$; intensity: NA; abundance: $\left.X^{2}=4.80, d f=1, P=0.029\right)$ and month $\left(A\right.$. sylvaticus prevalence: $X^{2}=54.53, d f=2$, $P<0.001$; intensity: $X^{2}=56.34, d f=2, P<0.001$; abundance: $X^{2}=97.93, d f=2, P<0.001 ; M$. spretus: prevalence: $X^{2}=7.15, d f=2, P=0.028$; intensity: NA; abundance: $\left.X^{2}=9.01, d f=2, P=0.011\right)$. The infestation was more prevalent and severe in July and among males than females in both host species. Furthermore, crop type explained variations in intensity and abundance in A. sylvaticus (intensity: $X^{2}=7.86, d f=2, P=$ 0.020; abundance: $X^{2}=6.15, d f=2, P<0.046$ ), with a greater intensity in hosts from cereal fields compared with fallows.

\section{Co-infections}

The majority of hosts were infested with one or two flea species $(63.2 \%$ and $34.5 \%$, respectively). Few hosts (2.3\%) harboured three flea species (Table 3). Higher coinfection rates were found in $M$. arvalis (38.8\%) and $A$. sylvaticus (34.6\%) than in M. spretus (13.3\%) and C. russula (16.7\%). Co-infection patterns with two flea species were diverse among hosts. Associations composed of C. a. gilcolladoi-N. fasciatus were most commonly found in $M$. arvalis (90.3\%), and very few co-infections with $L$. taschenbergi. In fact, this flea was collected alone in almost $90 \%$ of the cases. L. taschenbergi-N. fasciatus associations prevailed in the mouse hosts (A. sylvaticus $=$ $45.9 \%$; $M$. spretus $=66.7 \%$ ), although this predominance in A. sylvaticus was similar to the other co-infections $(C$. a. gilcolladoi-N. fasciatus: $30.3 \%$ and C. a. gilcolladoi-L . taschenbergi: 23.9\%; Fig. 1). These results were in agreement with the Fager index values obtained for pairs of flea species on these hosts (Table 3).

Co-infection rates did not differ between sexes in $M$. arvalis $\left(X^{2}=2.87, d f=1, P=0.090\right)$ or in $M$. spretus $(G=$ $2.90, d f=1, P=0.886)$, but did in $A$. sylvaticus $\left(X^{2}=5.89\right.$, $d f=1, P=0.015)$, with fewer co-infections in female than male hosts. Considering hosts infested with two or three species, we found no differences between sexes ( $M$. arvalis: $X^{2}=2.67, d f=1, P=0.102 ;$ A. sylvaticus: $G=2.63$, $d f=1, P=0.105)$. In terms of co-infection assemblies, male and female wood mice presented similar values of coinfection for all flea pairs $(G=0.87, d f=3, P=0.649)$. In voles, however, we found a male-biased $N$. fasciatus- $L$. taschenbergi co-infection, which occurred more frequently in male than in female hosts $\left(X^{2}=7.54, d f=1, P=0.006\right)$.

\section{Discussion}

The flea community parasitizing the small mammal guild studied here was mainly (99.4\%) composed by N. fasciatus, C. a. gilcolladoi and L. taschenbergi and showed species-specificity and marked aggregation patterns. We found strong sex-biased differences in the mouse hosts, lower flea infestation in voles captured from alfalfas, and seasonal variations differing between host and flea species. Interspecific co-infections were frequent, with up to three different flea species in some hosts.

\section{Flea community}

The northern rat flea ( $N$. fasciatus) was the most common and most abundant flea species in the studied small mammal community, parasitizing both rodents and insectivores. This flea mainly parasitizes rodents but can facultatively infest a wide range of mammalian hosts [48], which can explain their overall high abundance and prevalence rates. A pattern of generalist fleas reaching heavier infestations has also been reported in other systems [49]. Ctenophthalmus fleas are a generalist group that diverges in their distribution range owing to geographical specificity [50]. Although all Ctenophthalmus species identified here are endemic to the Western Mediterranean area, $C$. a. gilcolladoi is the typical flea of the open habitats of this region [50,51]. Leptopsylla taschenbergi was the most abundant flea found on A. sylvaticus and M. spretus, and showed a low infestation rate on common voles, which is consistent with its well-known mouse-specificity [51].

Our results show the typical aggregation pattern of fleas on rodents found elsewhere [52]. Poulin D-index values for the most abundant fleas $(N$. fasciatus and C. a. gilcolladoi) were lower in M. arvalis than in mice. Behavioural traits could explain these differences [19], since the social behaviour of common voles could facilitate the switching of fleas between hosts, reducing flea 
Table 3 Flea co-infection rates on the main hosts and Fager index for the most common flea associations

\begin{tabular}{|c|c|c|c|c|c|c|}
\hline \multirow[t]{3}{*}{ Host } & \multicolumn{3}{|c|}{ Flea species per host } & \multicolumn{3}{|c|}{ Fager index } \\
\hline & \multicolumn{3}{|c|}{ Prevalence\% [n host] } & \multicolumn{3}{|l|}{$[n$ host $]$} \\
\hline & 1 & 2 & 3 & CAG-LT & CAG-NF & LT-NF \\
\hline M. arvalis & $61.2[534]$ & $37.2[324]$ & $1.6[14]$ & $0.046[13]$ & $0.538[318]$ & $0.063[21]$ \\
\hline Male & $64.1[270]$ & 34.0 [143] & $1.9[8]$ & $0.060[8]$ & 0.498 [139] & $0.098[16]$ \\
\hline Female & $58.5[264]$ & $40.1[181]$ & $1.3[6]$ & $0.029[5]$ & $0.574[179]$ & $0.029[5]$ \\
\hline A. sylvaticus & $65.1[155]$ & $28.7[68]$ & $5.9[14]$ & $0.242[26]$ & $0.346[33]$ & $0.391[50]$ \\
\hline Male & 60.2 [97] & $31.7[51]$ & $8.1[13]$ & $0.273[22]$ & $0.424[28]$ & $0.442[40]$ \\
\hline Female & $76.3[58]$ & $22.4[17]$ & $1.3[1]$ & $0.148[4]$ & $0.169[5]$ & $0.267[10]$ \\
\hline M. spretus & $86.7[39]$ & $13.3[6]$ & 0 & $0.069[1]$ & $0.063[1]$ & $0.205[4]$ \\
\hline Male & $83.3[30]$ & $16.7[6]$ & 0 & $0.083[1]$ & $0.077[1]$ & $0.250[4]$ \\
\hline Female & $100.0[9]$ & 0 & 0 & 0 & 0 & 0 \\
\hline C. russula & $83.3[5]$ & $16.7[1]$ & 0 & 0 & $0.286[1]$ & 0 \\
\hline Male & $75.0[3]$ & $25.0[1]$ & 0 & 0 & $0.400[1]$ & 0 \\
\hline Female & $100.0[2]$ & 0 & 0 & 0 & 0 & 0 \\
\hline
\end{tabular}

1, one flea species; 2 , two co-occurrence flea species; 3 , three co-occurrence flea species. For flea species abbreviation (CAG, LT, NF) see Fig. 1

aggregation. Regarding variance-to-mean ratios, we found differences between $N$. fasciatus and C. a. gilcolladoi despite similar abundances. The host-generalist strategy of $N$. fasciatus [5] could explain the reduced aggregation level. Generalist parasites with broad habitat requirements, like $N$. fasciatus, would have access to more hosts, having more resources available and reducing intraspecific competition. Another important aspect to consider is the local asynchrony in abundance fluctuations of the rodent species (summer peak in voles versus autumn peaks in mice; $[13,53])$. Thereby, many potential hosts are accessible to generalist fleas during those high density periods throughout the year, potentially causing a dilution effect for $N$. fasciatus and lower its aggregation levels. Conversely, highly specialised fleas (such as L. taschenbergi) would tend to parasitize only the fewer suitable hosts that are available (i.e. A. sylvaticus and $M$. spretus).

\section{Variations of flea parasitological parameter variation according to season, crop type and host sex}

Microtus arvalis harboured the highest flea burden and infestation rate, followed by $A$. sylvaticus. Larger body size and greater complexity of the burrow system can lead to heavier flea infestations [54], which could explain the lower infestation rates in $M$. spretus and C. russula (although the sample size of the latter was too small to draw a solid conclusion). Moreover, the fossorial life of $M$. arvalis could increase the probability of getting infested by naïve fleas because burrows are used by preimaginal stages to develop until their first blood feeding [5].
We found seasonal variations in the main flea species whatever the rodent host. In general terms, prevalence models could be easily understood from a flea phenology point of view, since maximum values occurred during the season with the greatest flea activity: $C$. $a$. gilcolladoi showed higher presence in March/November, with a significant drop in July, and vice versa for $N$. fasciatus and L. taschenbergi, which is in accordance with previous studies $[5,48,51]$. At a global scale, $N$. fasciatus has no marked seasonality in Atlantic conditions [5]. However, N. fasciatus eggs require at least $23{ }^{\circ} \mathrm{C}$ during 4 days or a peak of $30{ }^{\circ} \mathrm{C}$ for $3 \mathrm{~h}$ to hatch $[55,56]$. The extreme cold conditions during the autumn-winter months in the study region (including November and March) may lead this species to shorten its reproductive period or modify its activity pattern, recovering in spring as the weather conditions become more suitable.

Seasonality in flea patterns is common as are variations owing to local climatic conditions and host traits $[18,22-24]$. Assuming the same phenology in individuals belonging to a certain species living under the same climatic conditions, differences in infestation parameters can be explained by host characteristics. The patterns obtained in this study also seemed to be influenced by particular hosts traits. Prevalence models followed the same general rule according to flea phenology, but many seasonal peculiarities arose considering variations in intensity regarding one host that did not show the others. Overall, maximum infestation rate occurred during summer, when small mammal species are more active and reproduce [35], potentially increasing the exposure 
of hosts through contacts with other infested animals [19]. However, we found that maximum infestation rate and maximum intensity occurred simultaneously during this favourable season in mice, but not in voles. The low flea abundance in voles during this favourable season for transmission, despite a high percentage of infected hosts, could be explained by a dilution effect owing to the increase in the population density of voles compared to colder months (see [13] for more details about host density dynamics). Similarly, the intensity of $N$. fasciatus also differed between voles and mice during July. Since the intensity and prevalence of voles increased significantly during the summer, the reproductive period of this flea [51], infestation burden remained low in mice until March. If burrows and mice themselves were as suitable as voles, no differences in intensity should exist between the two type of rodents. Nevertheless, intensity remained low in mice during the most suitable season for $N$. fasciatus reproduction. A possible reason could be that wood mouse nests or their own body are less suitable for this flea compared with voles. This type of differences at the host species level has been described in other small mammal communities [57]. Therefore, the maximum intensity of $N$. fasciatus in mice is reached at minimum mouse population abundance (after the winter mortality and before the spring reproductive recruitment) [13], which may facilitate the flea aggregation in the surviving animals. Furthermore, $A$. sylvaticus have a more individualistic behaviour and spend more time inside the burrows during the cold months [33], which could reduce the probability of flea transmission to other hosts, preventing a decrease in flea intensity [19].

A similar pattern may be occurring for C. a. gilcolladoi on wood mice in March when prevalence patterns differed from those on voles. A noticeable seasonality was found in the latter, following the typical flea phenology with peaks during temperate months $[5,51]$. We found lower infestation values and no differences in prevalence throughout the year in mice. These results suggest that $C$. a. gilcolladoi may prefer infesting common voles rather than mice in this ecosystem, although no investigation has been done yet to determine the relationship between C. a. gilcolladoi and their hosts in this system. This possible preference was not expected since $M$. arvalis is a host species that colonized the study region during the 1970s, invading from mountain habitats characterized by Atlantic weather conditions [10]. Ctenophthalmus apertus is endemic to Mediterranean open habitats and absent from Atlantic climatic areas [50]; thus, it does not occur within the original distribution range of $M$. arvalis. A host shift could have possibly occurred if this new host species offered better conditions than other hosts [57].
The colonization by a new species, the common vole, may therefore have altered the host-parasite system. If either of them acts as a reservoir or vector of any pathogen, the consequences and implications of this alteration could be unexpected $[58,59]$. Future investigation could elucidate the consequences of such shifts in terms of pathogen transmission risk.

We also found differences in flea parameters depending on the habitats used by hosts. Common voles inhabiting alfalfas had lower flea prevalence and abundance than those from other crop types. Leptopsylla taschenbergi infestation in voles also appeared associated with cereal habitats. Wood mice inhabiting cereals had heavier flea burdens compared with other habitats. Some authors have linked animal condition and abundance with the quality and quantity of food supply [60]. The most favourable crop type for voles is alfalfa, where they reach the highest densities and better body condition [60]. The wood mouse has a strong preference for woody habitats [61], avoiding habitats without shrub [62] and with insufficient cover to protect them from predators [63] such as cereals (especially recently sown crops in November and stubbles in July). Animals inhabiting sub-optimal habitats may have greater flea infestation because they are in worse condition, favouring the egg production and survival of flea larvae [64].

Lastly, we found sexual differences in flea infestation in both mice species, with greater prevalence and severity in male than in female hosts. Such patterns were not found in $M$. arvalis, except with the less frequent flea species, L. taschenbergi. This male-biased difference is usually linked to sexual size dimorphism, immunosuppression by sexual hormones, or behavioural differences that facilitates flea encounter and horizontal transmission [65]. Such patterns have been already reported in several mice species [22, 66, 67]. However, the absence of sex bias in our voles suggests that differences at the host scale may cause these dissimilarities. This may be due to the colonial lifestyle [68] and the aggressive behaviour of female voles [69] that could increase the horizontal transmission among females, balancing the flea burden between both sexes. Male voles are more mobile than females [68] and also more active [70] and therefore more prone to flea encounters [5], potentially explaining why the less frequent flea species (L. taschenbergi) occurred more often in male than in female voles.

\section{Co-infections and implications}

In the Mediterranean agricultural landscapes studied here, two dominant flea species ( $N$. fasciatus and $C$. $a$. gilcolladoi) were shared by $40 \%$ of the hosts of the small mammal guild. Flea co-occurrence is common in small 
mammals [71] and maybe due to apparent facilitation via suppression of the host immune system [72]. It is known that different fleas can be infected by the same pathogen [30], while several pathogens can be harboured by a shared host [7]. Since fleas are important vectors for many pathogens [1], coinfections could have important consequences in terms of disease dispersal and zoonotic transmission risk $[73,74]$, increasing the circulation of pathogens through a shared host population. Moreover, generalist and abundant fleas can infest animals living next to people and, eventually, bite humans. The generalist flea $N$. fasciatus was found in the most abundant coinfections of the four small mammals, with an apparently high tolerance to cohabit with other flea species. In fact, we identified this flea and C. a. gilcolladoi (the two more abundant fleas) in $82.7 \%$ of all the co-infections analysed. Notably, previous work [30] detected Bartonella spp. prevalences of $65 \%$ in $N$. fasciatus collected from our focal common vole population and of $33 \%$ in C. $a$. gilcolladoi. Additional investigation should therefore be carried out to determine the potential roles of these two fleas in the transmission of bartonelloses. Moreover, $N$. fasciatus is a typical parasite of Rattus spp. [1], and both fleas are known to parasitize Mus domesticus in Spain [75]. Rattus and Mus spp. commensal rodents are widespread in rural areas, especially linked to the presence of domestic livestock, and they can be infected by Bartonella sp. [76, 77]. Density can influence the flea-host system [20,21], and fluctuations in wild rodent densities can facilitate the encounters with commensal rodents, fleas and humans, increasing the possibility of disease transmission in the rural population inhabiting this agricultural area. The other flea species (other Ctenophthalmus spp. and $R$. beillardae) were more rarely found. Therefore, their possible role in the circulation cycle of zoonoses among this small mammal host guild would probably be less relevant.

\section{Conclusion}

Six different flea species parasitized the studied small mammal guild inhabiting continental Mediterranean farmland, although $C$. a. gilcolladoi and the generalist $N$. fasciatus were found to dominate the flea community. Co-infections with both flea species, which often harbour zoonotic pathogens, frequently occurred within the focal host guild. The role that flea species might play in zoonotic transmission should be elucidated, considering also seasonal patterns and sex-biased differences. Moreover, the most abundant host (i.e. $M$. arvalis) is a recent colonizer and, unlike other small mammal hosts, is characterized by large fluctuations in abundance. The consequences of fluctuating $M$. arvalis abundances for the transmission cycles of flea-vectored diseases should also be investigated.

\section{Supplementary information}

Supplementary information accompanies this paper at https://doi. org/10.1186/s13071-020-04492-6.

Additional file 1: Figure S1. Flea cumulative frequencies in the main small mammal host species. CAA, Ctenophthalmus apertus apertus; CAG, Ctenophthalmus apertus gilcolladoi; CB, Ctenophthalmus baeticus; NF, Nosopsyllus fasciatus; LT, Leptopsylla taschenbergi; RB, Rhadinopsylla beillardae. * Sample size too small $(n=1)$.

\section{Acknowledgements}

Not applicable.

\section{Authors' contributions}

$J J L L$ and FM obtained all the funding and designed the monitoring. JJLL, RRP and MFF collected the data. SHC, MFF and FM performed the statistical analysis. SHC and MFF drafted the manuscript. FM, JJLL and RRP critically revised the paper. All authors read and approved the final manuscript.

\section{Funding}

This work was funded by the projects ECOCYCLES (Partner 5-EUI2008-03658), ECOVOLE (CGL2012-35348) and ECOTULA (CGL2015-66962-C2-1-R). SHC was supported by a PhD studentship from Junta de Castilla-y-León (co-funded by the European Social Fund, Orden 10/11/2016). RRP was supported by a PhD studentship from the University of Valladolid (co-funded by Banco Santander, RR 30/04/2014).

\section{Availability of data and materials}

The datasets used and/or analysed during the current study are available from the principal investigator JJ Luque-Larena (j.luque@agro.uva.es) on reasonable request.

\section{Ethics approval and consent to participate}

The trapping methods applied in this study were approved by our institution ethics committee (CEEBA, Universidad de Valladolid; authorization code: 4801646) and we counted with the official trapping permits from DGMN (Junta de Castilla-y-León) as well as compulsory national certificates (B and C categories) to manipulate living animals for research.

Consent for publication

Not applicable.

Competing interests

The authors declare that they have no competing interests.

Author details

Dpto. Ciencias Agroforestales, ETSIIAA, Universidad de Valladolid, Avda. de Madrid 44, 34004 Palencia, Spain. ${ }^{2}$ Instituto Universitario de Investigación en Gestión Forestal Sostenible, Palencia, Spain. ${ }^{3}$ Dpto. Biología Animal (Zoología), Universidad de Salamanca, Campus Unamuno S/N, 37007 Salamanca, Spain. ${ }^{4}$ Instituto de Investigación en Recursos Cinegéticos, IREC (CSIC-UCLM-JCCM), Ronda de Toledo s/n, 13071 Ciudad Real, Spain.

Received: 5 August 2020 Accepted: 19 November 2020

Published online: 06 January 2021

\footnotetext{
References

1. Bitam I, Dittmar K, Parola P, Whiting MF, Raoult D. Fleas and flea-borne diseases. Int J Infect Dis. 2010. https://doi.org/10.1016/j.jij.2009.11.011.

2. Kruse H, Kirkemo A-M, Handeland K. Wildlife as Source of Zoonotic Infections. Emerg Infect Dis. 2004;10:2067-72.
} 
3. Stenseth NC, Atshabar BB, Begon M, Belmain SR, Bertherat E, Carniel E, et al. Plague: past, present, and future. PLoS Med. 2008. https://doi. org/10.1371/journal.pmed.0050003.

4. Durden LA, Hinkle NC. Fleas (Siphonaptera). In: Mullen GR, Durden LA editors. Med Vet Entomol. London: Elsevier Academic Press; 2019. p. 145-69.

5. Krasnov BR. Functional and evolutionary ecology of fleas. A model for ecological parasitology. New York: Cambridge University Press; 2008.

6. Lambin EF, Tran A, Vanwambeke SO, Linard C, Soti V. Pathogenic landscapes: interactions between land, people, disease vectors, and their animal hosts. Int J Health Geogr. 2010. https://doi. org/10.1186/1476-072X-9-54

7. Han BA, Schmidt JP, Bowden SE, Drake JM. Rodent reservoirs of future zoonotic diseases. Proc Natl Acad Sci. 2015. https://doi.org/10.1073/ pnas.1501598112.

8. Meerburg BG, Singleton GR, Kijlstra A. Rodent-borne diseases and their risks for public health. Crit Rev Microbiol. 2009. https://doi. org/10.1080/10408410902989837.

9. Han BA, Kramer AM, Drake JM. Global patterns of zoonotic disease in mammals. Trends Parasitol. 2016. https://doi.org/10.1016/j.pt.2016.04.007.

10. Luque-Larena JJ, Mougeot F, Viñuela J, Jareño D, Arroyo L, Lambin X, et al. Recent large-scale range expansion and outbreaks of the common vole (Microtus arvalis) in NW Spain. Basic Appl Ecol. 2013. https://doi. org/10.1016/j.baae.2013.04.006.

11. Jareño D, Viñuela J, Luque-Larena JJ, Arroyo L, Arroyo B, Mougeot F. Factors associated with the colonization of agricultural areas by common voles Microtus arvalis in NW Spain. Biol Invasions. 2015. https://doi. org/10.1007/s10530-015-0877-4.

12. Luque-Larena JJ, Mougeot F, Arroyo B, Lambin X. "Got rats ?" Global environmental costs of thirst for milk include acute biodiversity impacts linked to dairy feed production. Glob Chang Biol. 2018. https://doi. org/10.1111/gcb.14170.

13. Mougeot $F$, Lambin $X$, Rodríguez-Pastor R, Romairone J, Luque-Larena JJ. Numerical response of a mammalian specialist predator to multiple prey dynamics in Mediterranean farmlands. Ecology. 2019. https://doi. org/10.1002/ecy.2776.

14. Luque-Larena JJ, Mougeot F, Arroyo B, Vidal MD, Rodríguez-Pastor R, Escudero R, et al. Irruptive mammal host populations shape tularemia epidemiology. PLOS Pathog. 2017. https://doi.org/10.1371/journal.ppat.10066 22.

15. Rodríguez-Pastor R, Escudero R, Vidal D, Mougeot F, Arroyo B, Lambin X, et al. Density-dependent prevalence of Francisella tularensis in fluctuating vole populations Northwestern Spain. Emerg Infect Dis. 2017. https://doi. org/10.3201/eid2308.161194.

16. Rodríguez-Pastor R, Luque-Larena JJ, Lambin X, Mougeot F. "Living on the edge": The role of field margins for common vole (Microtus arvalis) populations in recently colonised Mediterranean farmland. Agric Ecosyst Environ. 2016. https://doi.org/10.1016/j.agee.2016.06.041

17. Kiffner C, Stanko M, Morand S, Khokhlova IS, Shenbrot GI, Laudisoit A, et al. Variable effects of host characteristics on species richness of flea infracommunities in rodents from three continents. Parasitol Res. 2014. https://doi.org/10.1007/s00436-014-3937-2.

18. Krasnov BR, Mouillot D, Shenbrot GI, Khokhlova IS, Poulin R. Geographical variation in host specificity of fleas (Siphonaptera) parasitic on small mammals: the influence of phylogeny and local environmental conditions. Ecography. 2004. https://doi.org/10.1111/j.0906-7590.2004.04015.x.

19. Krasnov BR, Khokhlova IS. The effect of behavioural interactions on the transfer of fleas (Siphonaptera) between two rodent species. J Vector Ecol. 2001;26:181-90.

20. Stanko M, Miklisová D, Gouy de Bellocq J, Morand S. Mammal density and patterns of ectoparasite species richness and abundance. Oecologia. 2002. https://doi.org/10.1007/s00442-002-0889-5.

21. Krasnov BR, Khokhlova IS, Shenbrot GI. The effect of host density on ectoparasite distribution: an example of a rodent parasitized by fleas. Ecology. 2002. https://doi.org/10.2307/2680129.

22. Kiffner C, Stanko M, Morand S, Khokhlova IS, Shenbrot GI, Laudisoit A, et al. Sex-biased parasitism is not universal: evidence from rodent-flea associations from three biomes. Oecologia. 2013. https://doi.org/10.1007/ s00442-013-2664-1.

23. Krasnov BR, Stanko M, Miklisova D, Morand S, Krasnov BR, Stanko M, Miklisova D, Morand S. Habitat variation in species composition of flea assemblages on small mammals in central Europe. Ecol Res. 2006. https:// doi.org/10.1007/s11284-005-0142-x.

24. Krasnov BR, Shenbrot GI, Khokhlova IS, Poulin R. Diversification of ectoparasite assemblages and climate: an example with fleas parasitic on small mammals. Glob Ecol Biogeogr. 2005. https://doi.org/10.1111/j.1466822X.2005.00146.X

25. Beaucournu JC, Gómez-Lopez MS. Orden Siphonaptera. Rev IDE@-SEA 2015;61:1-11.

26. Domínguez-Peñafiel G, Giménez-Pardo C, Gegúndez MI, Lledó L. Prevalence of ectoparasitic arthropods on wild animals and cattle in the Las Merindades area (Burgos, Spain). Parasite. 2011;18:251-60.

27. Dunnet GM. Records of small mammals and their fleas from Reinosa, Santander Spain. Ann Mag Nat Hist. 1955. https://doi.org/10.1080/00222 935508656071.

28. Lledó L, Giménez-Pardo C, Domínguez-Peñafiel G, Sousa R, Gegúndez MI, Casado N, et al. Molecular detection of hemoprotozoa and Rickettsia species in arthropods collected from wild animals in the Burgos province. Spain Vector-Borne Zoonotic Dis. 2010. https://doi.org/10.1089/ vbz.2009.0114

29. Domínguez G. North Spain (Burgos) wild mammals ectoparasites. Parasite. 2004. https://doi.org/10.1051/parasite/2004113267.

30. Rodríguez-Pastor R, Mougeot F, Vidal MD, Jado I, González-Martín-Niño $\mathrm{RM}$, Escudero R, et al. Zoonotic bacteria in fleas parasitizing common voles Northwestern Spain. Emerg Infect Dis. 2019. https://doi. org/10.3201/eid2507.181646.

31. Rivas-Martínez S, Penas Á, del Río S, Díaz González TE, Rivas-Sáenz S. Bioclimatology of the Iberian Peninsula and the Balearic Islands. In: Loidi J, editor. The vegetation of the Iberian Peninsula. Cham: Springer International Publishing; 2017. https://doi.org/10.1007/978-3-319-54784-8_2.

32. Hernández MC, Sánchez-González B, Navarro-Castilla Á, Barja I. Topillo campesino-Microtus arvalis (Pallas, 1779). In: Enciclopedia virtual de los vertebrados españoles. Museo Nacional de Ciencias Naturales. 2017 http://www.vertebradosibericos.org/. Accessed 29 Apr 2020

33. Torre I, Arrizabalaga A, Diaz M. Ratón de campo (Apodemus sylvaticus. Linnaeus, 1758). Galemys. 2002;14:1-26.

34. Palomo $\sqcup$, Justo ER, Vargas JM. Mus spretus (Rodentia: Muridae). Mamm Species. 2009. https://doi.org/10.1644/840.1/2600882.

35. Palomo $\sqcup$, Gisbert J, Blanco JC. Atlas y libro rojo de los mamíferos terrestres de España. Atlas y Libr rojo los mamíferos Terr España. 2007.

36. Jefatura del Estado. Ley 32/2007, de 7 de noviembre, para el cuidado de los animales, en su explotación, transporte, experimentación y sacrificio. In: Boletín Oficial del Estado. 2007. https://www.boe.es/buscar/act. php?id=BOE-A-2007-19321. Accessed 25 Sept 2020

37. Gullan PJ, Cranston PS. The insects: an outline of entomology. Oxford: Blackwell Publising Ltd; 2005.

38. Gómez MS, Martín Mateo M-P, Martínez-lbáñez MD. Malófagos, anopluros y sifonápteros. In: Barrientos JA, editor. Curso Práctico Entomol. Barcelona: Universitat Autònoma de Barcelona; 2004. p. 599-614.

39. Beaucournu J-C, Launay H. Nouvelles captures de puces (Siphonaptera) en Espagne et description de trois sous-especes nouvelles. Ann Soc Entomol Fr. 1978;14:281-92.

40. Bush AO, Lafferty KD, Lotz JM, Shostak AW. Parasitology meets ecology on its own terms: Margolis et al. revisited. J Parasitol. 1997:83:575-83.

41. Poulin R. The disparity between observed and uniform distributions: a new look at parasite aggregation. Int J Parasitol. 1993;23:937-44.

42. Reiczigel J, Marozzi M, Fábián I, Rózsa L. Biostatistics for parasitologists-a primer to quantitative parasitology. Trends Parasitol. 2019. https://doi. org/10.1016/j.pt.2019.01.003.

43. Fager EW. Determination and analysis of recurrent groups. Ecology. 1957. https://doi.org/10.2307/1943124.

44. Bates D, Mächler M, Bolker B, Walker S. Fitting linear mixed-effects models using Ime4. J Stat Softw. 2015. https://doi.org/10.18637/jss.v067.i01.

45. Bolker B, Skaug H, Maintainer JL. R2admb: "ADMB" to R Interface Functions; 2017 https://CRAN.R-project.org/package=R2admb. Accessed 20 June 2020.

46. Hervé M. Testing and plotting procedures for biostatistics; 2020. https:// cran.r-project.org/web/packages/RVAideMemoire/RVAideMemoire.pdf. Accessed 25 Sept 2020

47. R Core Team. R: the R Project for statistical computing. R Foundation for Statistical Computing. 2019. https://www.r-project.org/. Accessed 20 June 2020. 
48. Gómez MS, Blasco-Zumeta J. Pulgas (Insecta: Siphonaptera) colectadas en Los Monegros (Zaragoza). Zapateri Rev Aragon Entomol. 2001;9:85-9.

49. Krasnov BR, Poulin R, Shenbrot GI, Mouillot D, Khokhlova IS. Ectoparasitic "jacks-of-all-trades": relationship between abundance and host specificity in fleas (Siphonaptera) parasitic on small mammals. Am Nat. 2004. https ://doi.org/10.1086/423716.

50. Gómez MS, Fernández-Salvador R, Garcia R. First report of Siphonaptera infesting Microtus (Microtus) cabrerae (Rodentia-Muridae-Arvicolinae) in Cuenca, Spain and notes about the morphologic variability of Ctenophthalmus (Ctenophthalmus) apertus personatus (Insecta-SiphonapteraCtenophthalmidae). Parasite. 2003. https://doi.org/10.1051/paras ite/2003102127.

51. Beaucournu J-C, Launay H. Les puces (Siphonaptera): de France et du bassin méditerranéen occidental. Paris: Fédération française des sociétés de sciences naturelles; 1990.

52. Hawlena H, Khokhlova IS, Abramsky Z, Krasnov BR. Age, intensity of infestation by flea parasites and body mass loss in a rodent host. Parasitology. 2006. https://doi.org/10.1017/S0031182006000308

53. Rodríguez-Pastor R, Escudero R, Lambin X, Vidal MD, Gil H, Jado I, et al. Zoonotic pathogens in fluctuating common vole (Microtus arvalis) populations: occurrence and dynamics. Parasitology. 2019. https://doi. org/10.1017/S0031182018001543.

54. Krasnov BR, Stanko M, Khokhlova IS, Mošanský L, Shenbrot Gl, Hawlena $\mathrm{H}$, et al. Aggregation and species coexistence in fleas parasitic on small mammals. Ecography. 2006. https://doi.org/10.111 1/j.2005.0906-7590.04353.x.

55. labal QJ, Humphries DA. Temperature as a critical factor in the mating behaviour of the rat flea, Nosopsyllus fasciatus (Bosc.). Parasitology. 1970. https://doi.org/10.1017/S0031182000041214.

56. Sharif M. On the life history and the biology of the rat-flea, Nosopsyllus fasciatus (Bosc.). Parasitology. 1937. https://doi.org/10.1017/S003118200 002477X.

57. Krasnov BR, Mouillot D, Shenbrot GI, Khokhlova IS, Poulin R. Abundance patterns and coexistence processes in communities of fleas parasitic on small mammals. Ecography. 2005. https://doi.org/10.111 1/j.0906-7590.2005.04182.x.

58. Dunn AM, Hatcher MJ. Parasites and biological invasions: parallels, interactions, and control. Trends Parasitol. 2015. https://doi.org/10.1016/j. pt.2014.12.003.

59. Diagne C, Galan M, Tamisier L, D'Ambrosio J, Dalecky A, Bâ K, et al. Ecological and sanitary impacts of bacterial communities associated to biological invasions in African commensal rodent communities. Sci Rep. 2017. https://doi.org/10.1038/s41598-017-14880-1.

60. Jánová E, Heroldová M, Bryja J. Conspicuous demographic and individual changes in a population of the common vole in a set-aside alfalfa field. Ann Zool Fennici. 2008. https://doi.org/10.5735/086.045.0104.

61. Heroldová M, Bryja J, Zejda J, Tkadlec E. Structure and diversity of small mammal communities in agriculture landscape. Agric Ecosyst Environ. 2007. https://doi.org/10.1016/j.agee.2006.09.007.

62. Noguerales $\mathrm{V}$, Traba J, Mata C, Morales MB. Winter habitat selection and partitioning in two sympatric farmland small mammals: Apodemus sylvaticus and Mus spretus. Revue d'Écologie. 2015;70(1):70-82.

63. Tew TE, Macdonald DW. The effects of harvest on arable wood mice Apodemus sy/vaticus. Biol Conserv. 1993. https://doi.org/10.1016/00063207(93)90060-E.
64. Krasnov BR, Khokhlova IS, Arakelyan MS, Degen AA. Is a starving host tastier? Reproduction in fleas parasitizing food-limited rodents. Funct Ecol. 2005. https://doi.org/10.1111/j.1365-2435.2005.01015.x.

65. Krasnov BR, Bordes F, Khokhlova IS, Morand S. Gender-biased parasitism in small mammals: Patterns, mechanisms, consequences. Mammalia. 2012. https://doi.org/10.1515/mammalia-2011-0108.

66. Cevidanes A, Proboste T, Chirife AD, Millán J. Differences in the ectoparasite fauna between micromammals captured in natural and adjacent residential areas are better explained by sex and season than by type of habitat. Parasitol Res. 2016. https://doi.org/10.1007/s00436-016-4962-0.

67. Kowalski K, Bogdziewicz M, Eichert U, Rychlik L. Sex differences in flea infections among rodent hosts: is there a male bias? Parasitol Res. 2015. https://doi.org/10.1007/s00436-014-4231-z.

68. Romairone J, Jiménez J, Luque-Larena JJ, Mougeot F. Spatial capturerecapture design and modelling for the study of small mammals. PLoS ONE. 2018. https://doi.org/10.1371/journal.pone.0198766.

69. Heise S, Lippke J. Role of female aggression in prevention of infanticidal behavior in male common voles, Microtus arvalis (Pallas, 1779). Aggress Behav. 1997. https://doi.org/10.1002/(SICI)1098-2337(1997)23:4\%3c293 :AID-AB6\%3e3.0.CO;2-L.

70. Eccard JA, Herde A. Seasonal variation in the behaviour of a short-lived rodent. BMC Ecol. 2013. https://doi.org/10.1186/1472-6785-13-43.

71. Krasnov BR, Matthee S, Lareschi M, Korallo-Vinarskaya NP, Vinarski MV. Co-occurrence of ectoparasites on rodent hosts: null model analyses of data from three continents. Oikos. 2010. https://doi.org/10.111 1/j.1600-0706.2009.17902.x.

72. Cox FEG. Concomitant infections, parasites and immune responses. Parasitology. 2001. https://doi.org/10.1017/S003118200001698X.

73. Telfer S, Lambin X, Birtles RJ, Beldomenico PM, Burthe SJ, Paterson S, et al. Species interactions in a parasite community drive infection risk in a wildlife population. Science. 2010. https://doi.org/10.1126/science.11903 33.

74. Vaumourin E, Vourc'h G, Gasqui P, Vayssier-Taussat M. The importance of multiparasitism: examining the consequences of co-infections for human and animal health. Parasit Vectors. 2015. https://doi.org/10.1186/s1307 1-015-1167-9.

75. Sans-Fuentes MA. Ratón casero-Mus musculus Linnaeus, 1758. In: Enciclopedia Virtual los Vertebrados Españoles; 2017. http://digital.csic.es/ bitstream/10261/112032/10/musmus_V3.pdf. Accessed 29 Apr 2020.

76. Harrus S, Bar-Gal GK, Golan A, Elazari-Volcani R, Kosoy MY, Morick D, et al. Isolation and genetic characterization of a Bartonella strain closely related to Bartonella tribocorum and Bartonella elizabethae in Israeli commensal rats. Am J Trop Med Hyg. 2009. https://doi.org/10.4269/ajtmh.2009.81.55.

77. Hornok S, Földvári G, Rigó K, Meli ML, Gönczi E, Répási A, et al. Synanthropic rodents and their ectoparasites as carriers of a novel haemoplasma and vector-borne, zoonotic pathogens indoors. Parasit Vectors. 2015. https://doi.org/10.1186/s13071-014-0630-3.Figures.

\section{Publisher's Note}

Springer Nature remains neutral with regard to jurisdictional claims in published maps and institutional affiliations.

Ready to submit your research? Choose BMC and benefit from

- fast, convenient online submission

- thorough peer review by experienced researchers in your field

- rapid publication on acceptance

- support for research data, including large and complex data types

- gold Open Access which fosters wider collaboration and increased citations

- maximum visibility for your research: over 100M website views per year

At BMC, research is always in progress.

Learn more biomedcentral.com/submissions 